\title{
PERENCANAAN SALURAN DRAINASE PRIMER PARIT SUNGAI RAYA DI KOTA PONTIANAK
}

\author{
Atmi Ayu Sisdamantri \\ Program Studi Teknik Lingkungan, Universitas Tanjungpura, Pontianak \\ Email: atmiayu21@yahoo.com
}

\begin{abstract}
ABSTRAK
Perencanaan ini bertujuan untuk mengevaluasi atau memperhitungkan serta mendesain saluran drainase pada Parit Sungai Raya dalam mengalirkan air ke pembuangan akhir mengingat beban drainase yang semakin hari semakin bertambah sesuai dengan dimensi saluran yang direncanakan. Dalam perencanaan ini diawali dengan menganalisa frekuensi curah hujan untuk mendapatkan besarnya hujan rencana dan intensitas curah hujan untuk berbagai periode ulang. Kemudian untuk menganalisa debit yang dipengaruhi oleh pasang surut dan curah hujan dengan periode ulang 10 tahun digunakan suatu model matematika yang disebut program DUFLOW.

Berdasarkan simulasi program Duflow didapatkan debit aliran pada daerah hulu sebesar $7,845 \mathrm{~m}^{3} / \mathrm{dtk}$ dengan dimensi saluran untuk lebar penampang sebesar $12,57 \mathrm{~m}$ dan kedalaman sebesar $2,60 \mathrm{~m}$. Pada daerah tengah debit aliran sebesar $8,040 \mathrm{~m}^{3} / \mathrm{dtk}$ dengan dimensi saluran untuk lebar penampang sebesar 12,88 $\mathrm{m}$ dan kedalaman sebesar 2,60 m. Sedangkan pada daerah hilir debit aliran sebesar $8,862 \mathrm{~m}^{3} /$ dtk dengan dimensi saluran untuk lebar penampang sebesar 13,68 $\mathrm{m}$ dan kedalaman sebesar 2,70 $\mathrm{m}$. Sehingga dapat disimpulkan bahwa dimensi saluran Parit Sungai Raya mampu menampung kapasitas debit maksimum akibat pasang surut dan curah hujan yang tinggi. Namun masih ada beberapa titik dikawasan ini yang mengalami genangan banjir.
\end{abstract}

Kata kunci: Parit Sungai Raya Pontianak, Drainase Primer, Kapasitas Tampung

\begin{abstract}
This plan aims to evaluated or calculated and designed the primary drainage channel in Sungai Raya river to drain the water to the disposal of water that is considered the load drainage that is increasingly growing in accordance with the planned channel dimensions. In this plan begins by analyzing the frequency of precipitation for got amount of rain plan and rainfall intensity for various periods. Then to analyzed the discharge is affected by tidal and rainfall with return period of 10 years used a mathematical model called DUFLOW program.

Based on the simulation program Duflow obtained at flow rates of $7,845 \mathrm{~m}^{3} / d t k$ upstream with channel dimensions for a wide cross-section of $12,57 \mathrm{~m}$ and a depth of 2,60 $\mathrm{m}$. In the midstream of the flow rate of $8,040 \mathrm{~m}^{3} / \mathrm{dtk}$ with channel dimensions for a wide cross-section of $12,88 \mathrm{~m}$ and a depth of 2,60 m. While the downstream flow of $8,862 \mathrm{~m}^{3} / \mathrm{dtk}$ with channel dimensions for a wide cross-section of 13,68 $\mathrm{m}$ and a depth of 2,70 $\mathrm{m}$. It can be concluded that the channel dimensions for Sungai Raya River can accommodate a maximum discharge capacity due to tides and heavy rainfall. But there are still some points of this region experiencing floodwaters.
\end{abstract}

Keywords: Sungai Raya River in Pontianak, Primary Drainage, Load Capacity

\section{Pendahuluan}

Pada dasarnya sistem drainase dalam suatu wilayah sudah tersedia di alam atau disediakan oleh alam berupa sungai beserta saluran alami lain yang mengarah ke sungai induk. Peningkatan pertambahan penduduk yang membutuhkan pemukiman sebagai tempat tinggal maka penggunaan lahan semakin meningkat pula. Sehingga mengakibatkan terganggunya aliran air yang berlebih dan bertambahnya air yang harus dibuang melalui saluran pembuangan. Saluran yang telah adapun tidak 
memadai lagi untuk menampung buangan air yang berlebih, maka perlu memperbesar dimensi atau menambah saluran drainase. Hal ini untuk menghindari terjadinya genangan-genangan air yang dapat mengganggu aktifitas manusia.

Kawasan Sungai Raya Dalam merupakan kawasan yang saat ini berkembang menjadi dua bagian yaitu Kecamatan Pontianak Tenggara dan Kabupaten Kubu Raya. Dulunya kawasan ini merupakan kawasan perkebunan, namun semakin lama kawasan ini semakin berkembang. Hal ini dapat dilihat dari banyaknya pemukiman penduduk serta pembangunan infrastruktur lainnya seperti jalan, jembatan, perdagangan, dan fasilitas penunjang lainnya yang telah menyebabkan perubahan fungsi lahan atau tata guna lahan. Dengan adanya aktivitas pembangunan infrastruktur ini peruntukan yang semula merupakan daerah terbuka dengan fungsi lahan sebagai area yang bersifat permeable (dapat ditembus air) kemudian berubah menjadi area yang bersifat impermeable (tidak dapat ditembus air) sehingga menyebabkan terganggunya penyerapan air pada waktu musim hujan. Kondisi ini berdampak terhadap lebih dominannya aliran permukaan sehingga berpengaruh terhadap perubahan debit aliran yang masuk ke sungai. Selain itu, adanya pembangunan ini secara otomatis dapat mengurangi lahan terbuka dimana pada saat terjadinya limpasan air misalnya air hujan, tanah tidak dapat menyerap air secara sempurna sehingga menyebabkan terjadinya banjir didaerah tersebut.

Kawasan disekitar Parit Sungai Raya ini juga dipengaruhi oleh pasang surut dan intensitas curah hujan yang tinggi. Apabila terjadi hujan bersamaan dengan pasang surut maka di sekitar kawasan Parit Sungai Raya akan tergenang. Selain itu saluran drainase sebagai tempat penampungan air yang berlebihan juga belum dapat berfungsi dengan baik

Dengan melihat kondisi alam Kota Pontianak khususnya dikawasan Sungai Raya Dalam dan beberapa permasalahan di atas serta terbatasnya lahan untuk pembuatan saluran drainase yang lebar sesuai dengan kebutuhan, maka akan dicoba untuk mengevaluasi kapasitas tampung maksimum pada saluran jaringan drainase terhadap banjir maksimum dengan baik, sesuai dengan ketentuan yang berlaku.

\section{Metode Penelitian}

Data yang digunakan dalam perencanaan ini adalah data primer yang meliputi data dimensi dilapangan, data koordinat, data kecepatan aliran dan data pasang surut serta data sekunder yang meliputi data curah hujan 20 tahun dari stasiun PTK-11 Pontianak serta peta-peta seperti peta topografi, peta administrasi, peta saluran drainase dan peta tata guna lahan. Dalam penelitian ini digunakan analisa data hujan untuk mendapatkan metode yang sesuai dalam menganalisa hujan rencana, untuk mendapatkan intensitas curah hujan dan nilai debit rencana. Adapun perhitungan distribusi curah hujan digunakan tiga metode diantaranya Metode Normal, Metode Gumbel Tipe I, dan Metode Log Pearson Tipe III. Dari ketiga metode tersebut dipilih metode yang memiliki \% error yang relatif kecil yaitu Metode Log Pearson Tipe III. Setelah analisa frekuensi curah hujan diketahui maka didapatkan hujan rencana untuk berbagai periode ulang.

Selain itu analisa data lapangan (kecepatan aliran, lebar saluran dan kedalaman saluran) untuk mendapatkan nilai debit saluran eksisting dengan menghitung debit total akibat curah hujan ditambah pasang surut ditambah debit saluran sekunder. Selain itu untuk menganalisa debit yang dipengaruhi oleh pasang surut dan curah hujan dengan periode ulang 10 tahun digunakan suatu model matematika yang disebut program DUFLOW. Dimana hasil simulasi (output) dari program ini menghasilkan elevasi muka air, kecepatan aliran, dan debit puncak banjir.

\section{Hasil dan Pembahasan}

A. Analisa Data Hidrologi

1) Analisa Frekuensi Curah Hujan

Analisa Frekuensi dilakukan terhadap curah hujan pada stasiun PTK-11 Pontianak. Data curah hujan yang diperoleh berupa data curah hujan harian untuk masa pengamatan dari tahun 1991 hingga tahun 2010. Pengolahan data curah hujan harian maksimum bertujuan untuk mendapatkan parameter ststistik dan pemilihan metode distribusi yang sesuai. Data curah hujan harian maksimum yang telah diolah dapat dilihat pada Tabel 1 berikut ini. 
Tabel 1: Data Curah Hujan Satu Harian Maksimum (mm/hari) Stasiun PTK-11 Pontianak Tahun 1991-2010

\begin{tabular}{|c|c|c|}
\hline No. & Tahun & Maks \\
\hline 1 & 1991 & 150 \\
\hline 2 & 1992 & 124 \\
\hline 3 & 1993 & 170 \\
\hline 4 & 1994 & 81 \\
\hline 5 & 1995 & 153 \\
\hline 6 & 1996 & 96 \\
\hline 7 & 1997 & 122 \\
\hline 8 & 1998 & 145 \\
\hline 9 & 1999 & 177 \\
\hline 10 & 2000 & 106 \\
\hline 11 & 2001 & 98 \\
\hline 12 & 2002 & 103 \\
\hline 13 & 2003 & 184 \\
\hline 14 & 2004 & 120 \\
\hline 15 & 2005 & 127 \\
\hline 16 & 2006 & 134 \\
\hline 17 & 2007 & 129 \\
\hline 18 & 2008 & 109 \\
\hline 19 & 2009 & 133 \\
\hline 20 & 2010 & 129 \\
\hline
\end{tabular}

2) Penentuan Metode Analisa Frekuensi yang Cocok/Mendekati

Setelah semua data curah hujan harian maksimum didapatkan, maka langkah selanjutnya adalah mengurutkan data dari yang terbesar ke yang terkecil. Kemudian menentukan Metode Distribusi frekuensi dilakukan dengan cara menghitung nilai koefisien skewness (Cs), koefisien kurtosis (Ck), dan koefisien variasi ( $\mathrm{Cv}$ ) dari data curah hujan satu harian maksimum. Lalu dibandingkan dengan beberapa Metode Distribusi antara lain Distribusi Normal, Log Normal, Gumbel, dan Log Pearson Type III sehingga nilai perhitungannya cocok atau mendekati.

Dari pengujian yang dilakukan dengan menggunakan Chi Kuadrat $\left(\mathrm{Xh}^{2}\right)$ terhadap ketiga metode diatas didapatkan bahwa metode yang diterima adalah Metode Gumbel Tipe I dan Log Pearson Tipe III. Karena ada dua metode yang diuji diterima, maka penggunaan metode yang sesuai untuk perhitungan analisa intensitas curah hujan adalah metode yang memiliki \% error yang relatif kecil, yaitu Metode Log Pearson Tipe III.

Kemudian untuk mencari Curah Hujan Rencana digunakan rumus :

$\log X \operatorname{tr}=\log X+(K n \cdot S \log X)$

Dengan nilai K untuk tiap-tiap periode ulang 2, 5, 10 dan 20 tahun diantaranya 0; 0,84; 1,28 dan 1,64. Maka didapatkan besarnya hujan rencana untuk berbagai periode ulang diantaranya $R_{2}=127 \mathrm{~mm}, R_{5}$ $=152 \mathrm{~mm}, \mathrm{R}_{10}=167 \mathrm{~mm}$, dan $\mathrm{R}_{20}=180 \mathrm{~mm}$.

Setelah nilai debit rencana didapat, maka Intensitas Hujan dapat dihitung dengan menggunakan rumus Mononobe berikut ini : $I=\left(\frac{R_{24}}{\mathbf{2 4}}\right)\left(\frac{\mathbf{2 4}}{T c}\right)^{\mathbf{m}}$

Maka didapatkan nilai Intensitas Hujan dengan periode ulang 2, 5, 10, dan 20 tahun masing-masing adalah 14,13 mm/jam; 15,19 mm/jam; 15,77 mm/jam dan 16,25 mm/jam.

B. Perhitungan Debit

1) Perhitungan Kecepatan Aliran Rata-rata

Dari pengukuran kecepatan aliran dengan menggunakan alat Current Meter digital pada penampang $1 / 4 T, 1 / 2 T, 3 / 4 \mathrm{~T}$ didapatkan hasil pengukuran. Adapun kecepatan aliran rata-rata diambil contoh pada titik 1 yang dapat dilihat pada Tabel 2 berikut ini. 
Tabel 2: Kecepatan Aliran Rata-Rata pada Titik 1

\begin{tabular}{|c|c|c|c|c|c|c|c|c|}
\hline $\begin{array}{c}\text { No } \\
\text { Titik }\end{array}$ & $\begin{array}{c}\text { Hari/Tanggal/ } \\
\text { Waktu }\end{array}$ & $\begin{array}{c}\mathbf{T} \\
\text { (pias) }\end{array}$ & $\begin{array}{c}\mathbf{Y} \\
(\mathbf{m})\end{array}$ & $\begin{array}{c}\mathbf{V} \mathbf{0 , 2 h} \\
(\mathbf{m} / \text { det })\end{array}$ & $\begin{array}{c}\mathbf{V} \mathbf{0 , 6 h} \\
(\mathbf{m} / \text { det})\end{array}$ & $\begin{array}{c}\mathbf{V} \mathbf{0 , 8 h} \\
(\mathbf{m} / \text { det})\end{array}$ & $\begin{array}{c}\mathbf{V} \\
\text { (m/det) }\end{array}$ & $\begin{array}{c}\mathbf{V}_{\text {rata-rata }} \\
\text { (m/det) }\end{array}$ \\
\hline 1 & Sabtu/23-06- & $1 / 4$ & 2,18 & 0,3 & 0,2 & 0,1 & 0,200 & \\
& $2012 / 8.00$ & $1 / 2$ & 2,45 & 0,5 & 0,3 & 0,2 & 0,325 & 0,24 \\
& & $3 / 4$ & 1,92 & 0,3 & 0,2 & 0,1 & 0,200 & \\
\hline
\end{tabular}

Dari tabel diatas dapat dilihat bahwa besarnya kecepatan aliran rata-rata pada titik 1 sebesar $0,24 \mathrm{~m} /$ det.

\section{2) Perhitungan Dimensi Saluran dan Debit Lapangan}

Untuk menghitung dimensi saluran dan debit lapangan digunakan rumus : Qs = As $\times$ V. Dibawah ini adalah perhitungan dimensi saluran dan debit lapangan di Parit Sungai Raya pada section 1 (bagian hulu), perhitungannya dapat dilihat dibawah ini :

$$
\begin{array}{rll}
\text { Diketahui : } & \mathrm{b} & =12,20 \mathrm{~m} \\
\mathrm{y} & =2,48 \mathrm{~m} \\
\mathrm{~V}_{\text {rata-rata }} & =0,24 \mathrm{~m} / \text { det }
\end{array}
$$

Dengan $b=$ lebar saluran

$\mathrm{Y}=$ kedalaman saluran

$\mathrm{V}_{\text {rata-rata }}=$ kecepatan rata-rata

As $=(\mathrm{b} \times \mathrm{y})$

$=(12,20 \times 2,48)$

$=30,26 \mathrm{~m}^{2}$

$P \quad=2 b+2 Y$

$=(2 \times 12,20)+(2 \times 2,48)$

$=29,36 \mathrm{~m}$

$\mathbf{R}=\frac{A}{P}$

$=\frac{30,26}{29,36}$

$=1,03 \mathrm{~m}$

Setelah nilai A (Luas saluran), P (Keliling saluran), dan R (Jari-jari hidrolik) didapatkan, maka untuk mencari nilai $S$ (kemiringan saluran) dapat digunakan rumus berikut ini (dengan menggunakan nilai $V_{\text {maks }}$ dari $V$ rata-rata dilapangan yaitu 0,24$)$ :

$$
\begin{aligned}
\mathbf{V} & =\frac{1}{n} \boldsymbol{x} \boldsymbol{R}^{2 / 3} \boldsymbol{S}^{\frac{1}{2}} \\
\mathrm{~S} & =\left[\frac{V}{\frac{1}{n} \times R^{2 / 3}}\right]^{2} \\
& =\left[\frac{0,24}{\frac{1}{0,025} \times 1,03^{2 / 3}}\right]^{2} \\
& =0,000038 \mathrm{~m}
\end{aligned}
$$

Sehingga, $\quad \mathbf{Q}=\mathbf{A s}$. V

$$
\begin{aligned}
& Q=30,26 \mathrm{~m}^{2} \times 0,24 \mathrm{~m} / \text { det } \\
& Q=7,31 \mathrm{~m}^{3} / \text { det }
\end{aligned}
$$

\section{Perhitungan Debit Total}

Debit total didapatkan dari hasil penjumlahan antara Debit Curah Hujan, Debit Pasang Surut dan Debit Saluran Sekunder.

Adapun debit yang didapatkan berdasarkan rumus berikut: $Q_{\text {curah hujan }}=0,002778 \times C \times I \times A$ (dengan $C=0,1$ (jika rerumputan $2-7 \%$ ), $\mathrm{I}_{10}=15,77 \mathrm{~mm} / \mathrm{jam}$ dan $\mathrm{A}=$ luas catchment area pada node 1 adalah $2,808 \mathrm{ha}$ ). $\mathrm{Q}_{\text {pasut }}=\mathrm{V} \times \mathrm{A}$ (dengan muka air tertinggi sebesar 2,46 $\mathrm{m}$ dan muka air terendah sebesar $0,43 \mathrm{~m}$ ) dan $Q_{\text {saluran sekunder }}=\mathrm{V} \times \mathrm{A}$.

Berikut ini didapatkan hasil dari debit total pada setiap section, yang dapat dilihat pada Tabel 3 berikut ini : 
Tabel 3: Perhitungan Debit Total pada Setiap Section

\begin{tabular}{|c|c|c|c|c|c|c|c|c|c|}
\hline Section & $\begin{array}{c}Q_{c h} \\
\left(\mathrm{~m}^{3} / \text { det }\right)\end{array}$ & $\underset{\substack{Q_{\text {pasut }} \\
\left(\mathrm{m}^{3} / \text { det }\right)}}{ }$ & $\begin{array}{c}\mathbf{Q}_{\text {sal. }} \\
\text { sekunder } \\
\left(\mathrm{m}^{3} / \mathrm{det}\right)\end{array}$ & $\begin{array}{c}Q_{\text {total }} \\
\left(\mathrm{m}^{3} / \text { det }\right)\end{array}$ & Section & $\begin{array}{c}Q_{c h} \\
\left(m^{3} / \text { det }\right)\end{array}$ & $\underset{\left(m^{3} / \text { det }\right)}{Q_{\text {pasut }}}$ & $\begin{array}{c}\mathbf{Q}_{\text {sal. }} \\
\text { sekunder } \\
\text { (m³ } / \text { det })\end{array}$ & $\begin{array}{c}Q_{\text {total }} \\
\left(\mathrm{m}^{3} / \text { det }\right)\end{array}$ \\
\hline 1 & 0,012 & 7,25 & - & 7,265 & 37 & 0,031 & 6,66 & - & 6,690 \\
\hline 2 & 0,007 & 6,40 & - & 6,403 & 38 & 0,035 & 6,84 & - & 6,872 \\
\hline 3 & 0,010 & 6,78 & - & 6,787 & 39 & 0,036 & 6,66 & - & 6,695 \\
\hline 4 & 0,006 & 4,69 & - & 4,692 & 40 & 0,038 & 6,54 & - & 6,577 \\
\hline 5 & 0,006 & 6,26 & - & 6,269 & 41 & 0,026 & 5,46 & - & 5,489 \\
\hline 6 & 0,010 & 5,43 & - & 5,443 & 42 & 0,033 & 6,54 & - & 6,573 \\
\hline 7 & 0,032 & 5,12 & - & 5,157 & 43 & 0,027 & 3,99 & - & 4,012 \\
\hline 8 & 0,052 & 5,91 & - & 5,964 & 44 & 0,034 & 6,30 & - & 6,336 \\
\hline 9 & 0,008 & 5,91 & - & 5,920 & 45 & 0,041 & 5,50 & - & 5,540 \\
\hline 10 & 0,033 & 6,24 & - & 6,275 & 46 & 0,041 & 5,05 & - & 5,089 \\
\hline 11 & 0,042 & 4,21 & - & 4,248 & 47 & 0,047 & 3,69 & - & 3,732 \\
\hline 12 & 0,038 & 5,69 & - & 5,727 & 48 & 0,054 & 4,42 & - & 4,474 \\
\hline 13 & 0,078 & 6,63 & - & 6,706 & 49 & 0,090 & 4,73 & - & 4,817 \\
\hline 14 & 0,037 & 5,54 & - & 5,572 & 50 & 0,027 & 5,56 & - & 5,586 \\
\hline 15 & 0,037 & 5,23 & - & 5,264 & 51 & 0,030 & 5,54 & - & 5,565 \\
\hline 16 & 0,016 & 6,79 & - & 6,806 & 52 & 0,009 & 6,09 & - & 6,103 \\
\hline 17 & 0,024 & 3,93 & - & 3,954 & 53 & 0,010 & 6,42 & - & 6,431 \\
\hline 18 & 0,009 & 5,30 & - & 5,313 & 54 & 0,011 & 5,76 & - & 5,768 \\
\hline 19 & 0,060 & 5,74 & - & 5,800 & 55 & 0,029 & 6,24 & - & 6,271 \\
\hline 20 & 0,030 & 6,05 & 0,024 & 6,101 & 56 & 0,031 & 6,75 & 0,010 & 6,788 \\
\hline 21 & 0,035 & 6,54 & - & 6,578 & 57 & 0,031 & 6,45 & 0,041 & 6,521 \\
\hline 22 & 0,009 & 6,46 & - & 6,466 & 58 & 0,033 & 6,23 & - & 6,259 \\
\hline 23 & 0,027 & 5,33 & - & 5,357 & 59 & 0,037 & 6,46 & - & 6,495 \\
\hline 24 & 0,044 & 5,02 & - & 5,067 & 60 & 0,035 & 6,05 & - & 6,088 \\
\hline 25 & 0,040 & 5,64 & 0,045 & 5,722 & 61 & 0,009 & 6,23 & - & 6,236 \\
\hline 26 & 0,036 & 6,66 & - & 6,695 & 62 & 0,009 & 6,72 & - & 6,727 \\
\hline 27 & 0,027 & 6,06 & - & 6,091 & 63 & 0,010 & 6,81 & - & 6,817 \\
\hline 28 & 0,030 & 6,40 & 0,0004 & 6,427 & 64 & 0,009 & 6,23 & - & 6,236 \\
\hline 29 & 0,033 & 6,90 & - & 6,929 & 65 & 0,008 & 7,19 & - & 7,201 \\
\hline 30 & 0,031 & 4,43 & - & 4,459 & 66 & 0,037 & 7,19 & - & 7,230 \\
\hline 31 & 0,007 & 6,40 & - & 6,403 & 67 & 0,035 & 7,07 & - & 7,109 \\
\hline 32 & 0,007 & 6,48 & - & 6,487 & 68 & 0,039 & 7,02 & 0,027 & 7,081 \\
\hline 33 & 0,007 & 6,48 & - & 6,487 & 69 & 0,036 & 4,65 & - & 4,686 \\
\hline 34 & 0,037 & 6,31 & - & 6,351 & 70 & 0,039 & 6,77 & 0,131 & 6,939 \\
\hline 35 & 0,039 & 6,31 & - & 6,353 & 71 & 0,005 & 6,46 & - & 6,462 \\
\hline 36 & 0,037 & 6,13 & - & 6,166 & 72 & 0,009 & 7,97 & 0,078 & 8,053 \\
\hline & & & & & & Jumlah & 432,84 & 0,36 & 435,25 \\
\hline
\end{tabular}

Dari tabel diatas maka dapat dilihat besarnya debit total pada debit total di Parit Sungai Raya pada daerah hulu, tengah dan hilir adalah sebesar $7,265 \mathrm{~m}^{3} /$ det, $6,166 \mathrm{~m}^{3} /$ det dan $8,053 \mathrm{~m}^{3} /$ det. 


\section{Analisa dengan Model Matematik Duflow}

1) Prosedur Inputing Data

Pemasukan data (inputing) kedalam program duflow dapat dimulai setelah terlebih dahulu menrunning file Duflow. EXE pada computer yang sudah terlebih dahulu diinstalkan program tersebut dengan lengkap dan benar. Setelah menrunning file tersebut maka dilayar komputer akan muncul halaman depan program tersebut.

\section{2) Simulasi Hasil Matematik}

Simulasi model matematik dilakukan dengan menyusun permodelan dengan kondisi-kondisi yang akan ditinjau. Dengan demikian, maka akan diketahui keadaan aliran pada keadaan ekstrim. Simulasi dilakukan pada kondisi normal, dimana data masukan kondisi batas yang digunakan sebagai syarat batas adalah level muka air, dengan curah hujan 1 harian maksimun dengan periode ulang 10 tahun.

Skema Model matematis untuk sistem ini adalah seperti terdapat pada network jaringan. Skema model jaringan akan terbentuk setelah masing-masing ruas tersebut yang berupa kode titik (node) dimasukkan. Setelah kode titik-titik tersebut selesai dimasukkan, dilanjutkan dengan memasukkan nilai $X$ dan $Y$, masing-masing titik-titik (node) tersebut. Data nilai $X$ dan $Y$ tersebut diperoleh dari hasil pengukuran topografi dilapangan. Setelah data tersebut dimasukkan, maka program akan secara langsung menghitung panjang masing-masing ruas.

Syarat batas (Boundrary condition) berguna mengontrol perhitungan, sehingga dapat lebih mendekati keadaan yang sebenarnya. Kondisi batas tersebut dapat dianggap mewakili keadaan alam yang sebenarnya, sehingga apabila ada pengaruh dari luar yang luput dari perhitungan, dapat diwakili oleh kondisi tersebut. Dalam perencanaan ini, kondisi batas yang digunakan adalah level muka air yang didapat dari pengukuran pasang surut pada sistem ini adalah pada node 73 yaitu muara Parit Sungai Raya dengan fluktuasi muka air 15 hari data pengamatan dan curah hujan maksimum 1 harian dengan periode ulang 10 tahun dari data curah hujan stasuin terdekat yaitu stasiun PTK-11 Kota Pontianak selama 20 tahun terakhir dari tahun 1991 s/d 2010 yang dianalisa dengan beberapa metode yang umum digunakan seperti yang telah diuraikan sebelumnya.

\section{3) Hasil Simulasi}

Dengan menjalankan program DUFLOW berdasarkan data masukan masing-masing kondisi, maka hasil simulasi dapat dilihat langsung di layar. Hasil simulasi dapat berupa grafik untuk masingmasing kondisi yang dapat dilihat pada gambar grafik boundary type I \& type II dibawah ini.

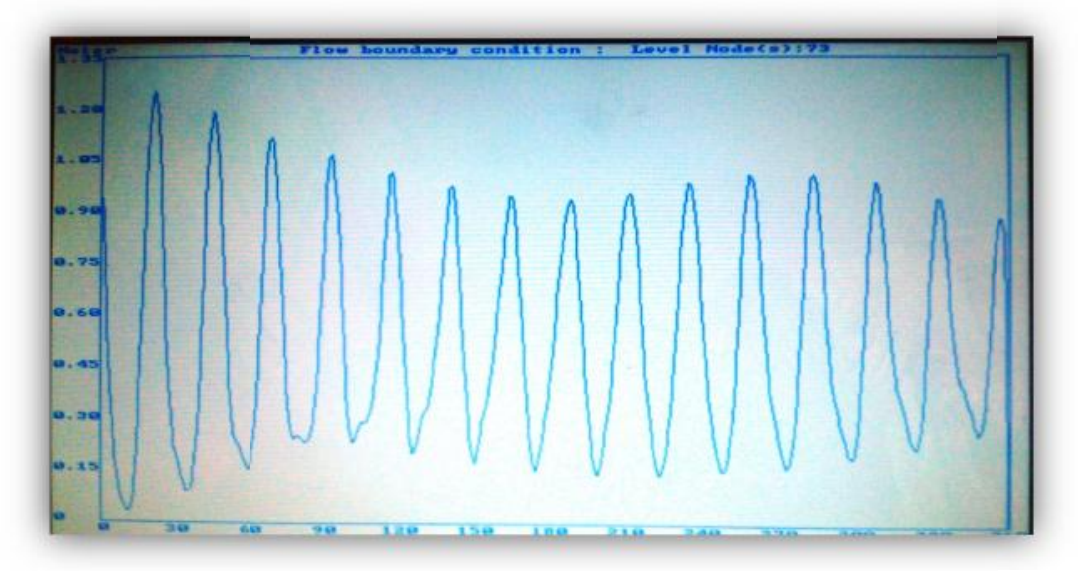

a. Grafik Syarat Batas Pasang Surut di Muara Parit Sungai Raya 


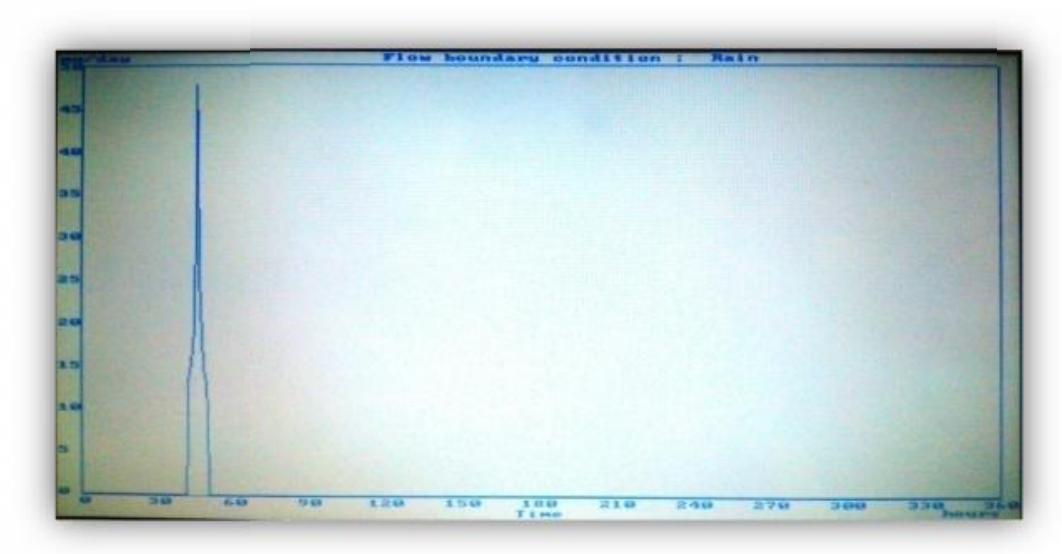

b. Grafik Syarat Batas Curah Hujan Periode Ulang 10 Tahun

Gambar.1 Grafik boundary type I \& type II

Dari gambar Boundary Condition Type II atau grafik syarat batas curah hujan periode ulang 10 Tahun diatas Level Puncak Pasang terletak pada hari pertama pukul 21.00 WIB, dengan tinggi level muka air $+1,25 \mathrm{~m}$ dan level muka air terendah 0,03.

\section{E. Perencanaan Dimensi Saluran}

Sistem drainase harus secara aman dapat mengalirkan debit banjir, yang ditentukan dengan kriteria periode ulang tanpa menimbulkan korban jiwa, harta benda dan bangunan-bangunan drainase itu sendiri. Oleh karena itu, dari hasil perhitungan yang ada, maka dapat didesain penampang saluran dimana debit rencana harus mampu menampung debit rencana (dengan ini menggunakan periode ulang 10 tahun) atau dengan kata lain persamaan $Q r \geq Q t$, dimana $\operatorname{Qr}$ (debit rencana yang didapat dari hasil simulasi program Duflow) harus dapat menampung Qt (debit total).

Adapun dalam perencanaan ini penulis mencoba untuk mendesain drainase dengan penampang berbentuk Persegi dengan menggunakan debit maksimum hasil dari simulasi Program Duflow. Mendesain drainase ini dengan cara melakukan perhitungan coba-coba (Trial and Error) untuk harga kecepatan aliran (V) dengan nilai debit (Q) yang sudah diketahui. Berikut ini akan ditampilkan contoh perhitungan Dimensi saluran pada daerah Hulu dengan menggunakan Debit hasil Program Duflow.

Diketahui :

$\mathrm{Q}=7,845 \mathrm{~m}^{3} /$ det

Penyelesaian:

Dicoba $V=0,24 \mathrm{~m} /$ det $\quad$ (nilai $\mathrm{V}_{\text {maks }}$ yang digunakan diambil dari $\mathrm{V}_{\text {maks }}$ rata-rata dilapangan yaitu Maka, $\mathrm{Q}_{\text {maks }}=$ As $\times \mathrm{V}$

$7,845 \mathrm{~m}^{3} /$ det $=$ As $\times 0,24 \mathrm{~m} / \mathrm{det}$

$$
\text { As } \begin{aligned}
\text { As } & =\frac{7,845 \mathrm{~m}^{3} / \mathrm{det}}{0,24 \mathrm{~m} / \mathrm{det}^{t}} \\
\text { As } & =32,688 \mathrm{~m}^{2} / \mathrm{det}
\end{aligned}
$$

Mencari lebar ( $b$ ) dan kedalaman ( $Y$ ) juga menggunakan cara coba-coba (Trial and Error), sebagai berikut :

Misal : $Y+W=2,6 \mathrm{~m} \quad$ (Nilai $Y$ yang digunakan dalam perencanaan ini adalah nilai $Y$ yang telah ditambah dengan $W$ (tinggi jagaan). Adapun nilai tinggi jagaan ini ditentukan sesuai dengan debit total yang ada. Dalam perhitungan ini $Q$ $=7,845 \mathrm{~m}^{3} /$ det $(\mathrm{Q}$ antara 6-10) maka Wmaks $=0,7$, maka dalam diambil nilai $\mathrm{W}=0,4 \mathrm{~m}^{3} /$ det. Sehingga didapat nilai $\mathrm{Y}+\mathrm{W}=2,6 \mathrm{~m}$.

$\begin{aligned} \text { Maka: As } & =b \times Y \\ 32,688 & =b \times 2,6 \\ b & =\frac{32,688 \mathrm{~m}^{2} / \text { det }}{2,6 \mathrm{~m}} \\ \mathrm{~b} & =12,57 \mathrm{~m}\end{aligned}$


Untuk desain lebih lengkapnya, dapat dilihat pada tabel dibawah ini.

Tabel 4: Desain Drainase dengan Penampang Persegi di Daerah Hulu, Tengah, dan Hilir Parit Sungai Raya

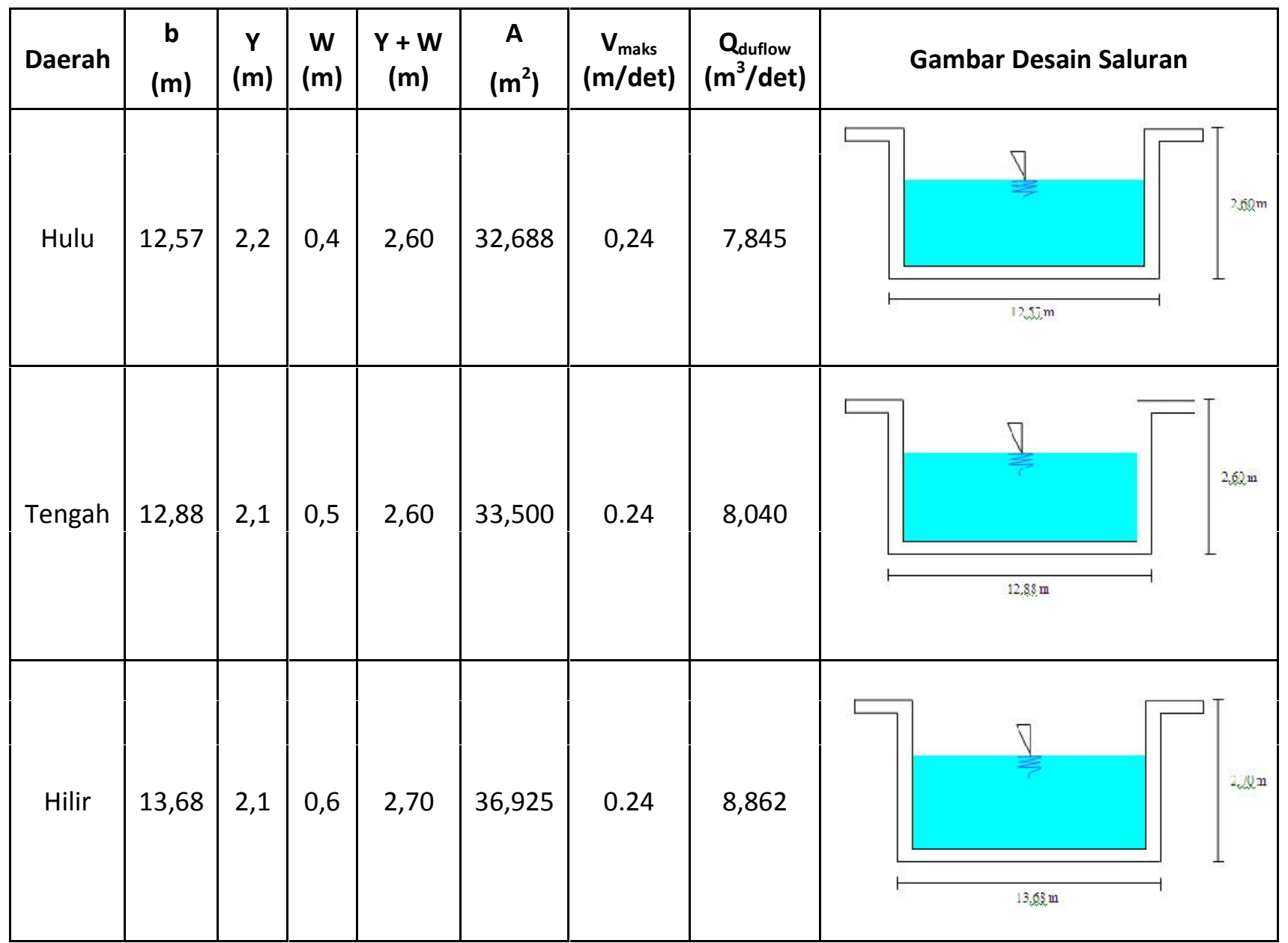

\section{F. Pembahasan}

Dari hasil perencanaan yang dilakukan dimana Parit Sungai Raya dipengaruhi oleh pasang surut dan curah hujan yang tinggi. Pada musim penghujan, curah hujan yang tinggi akan mengakibatkan banjir pada penampang saluran yang melebihi tebing sungai sehingga menyebabkan terjadinya banjir bahkan mengakibatkan bobolnya tanggul. Apalagi saat terjadi pasang surut dan curah hujan yang tinggi secara bersamaan.

Pada pengukuran dilapangan debit aliran saluran pada daerah hulu, tengah dan hilir adalah sebesar 7,31 $\mathrm{m}^{3} / \mathrm{dtk}, 5,98 \mathrm{~m}^{3} / \mathrm{dtk}$, dan $8,42 \mathrm{~m}^{3} / \mathrm{dtk}$. Sedangkan debit total di Parit Sungai Raya pada daerah hulu, tengah dan hilir adalah sebesar $7,265 \mathrm{~m}^{3} /$ det, $6,166 \mathrm{~m}^{3} /$ det dan $8,053 \mathrm{~m}^{3} /$ det. Maka dapat dilihat bahwa didaerah hilir debit alirannya lebih besar dari daerah hulu dan tengah.

Sedangkan dengan menggunakan program duflow ini didapatkan debit aliran pada daerah hulu sebesar $7,845 \mathrm{~m}^{3} / \mathrm{dtk}$ dengan dimensi saluran untuk lebar penampang sebesar $12,57 \mathrm{~m}$ dan kedalaman sebesar 2,60 m. Pada daerah tengah debit aliran sebesar $8,040 \mathrm{~m}^{3} / \mathrm{dtk}$ dengan dimensi saluran untuk lebar penampang sebesar $12,88 \mathrm{~m}$ dan kedalaman sebesar 2,60 m. Sedangkan pada daerah hilir debit aliran sebesar $8,862 \mathrm{~m}^{3} / \mathrm{dtk}$ dengan dimensi saluran untuk lebar penampang sebesar 13,68 m dan kedalaman sebesar 2,70 m. Dalam simulasi duflow ini juga terjadi genangan dibeberapa section yang disebabkan karena terjadi penyempitan saluran, ditumbuhi oleh vegetasi dan ada beberapa bangunan yang berdiri dibadan Parit Sungai Raya.

Perbedaan debit dan kecepatan antara hasil pengukuran dilapangan dan perhitungannya dengan hasil menggunakan program Duflow ini dikarenakan adanya perbedaan kondisi dilapangan. Salah satunya pada saat pengukuran pasang yang terjadi bukan pasang yang tertinggi disertai hujan, 
sedangkan pada simulasi tersebut merupakan pasang tertinggi dikondisikan dengan curah hujan harian maksimum dengan periode 10 tahun sehingga debit dan kecepatan yang dihasilkan berbeda.

Jika dilihat dari perbandingan antara debit saluran dan debit total, maka dapat dilihat bahwa dimensi saluran Parit Sungai Raya mampu menampung kapasitas debit air pasang disertai debit curah hujan yang tinggi. Namun masih ada beberapa titik dikawasan ini yang masih tergenang, terutama didaerah sungai raya bagian kota (sebelah kiri). Sedangkan disebelah kanan yang merupakan daerah sungai raya bagian Kubu Raya tidak terjadi banjir. Hal ini disebabkan karena elevasi sebelah kanan lebih tinggi dibandingkan sebelah kiri, dimana sebelah kanan saluran merupakan jalan raya. Genangan yang sering terjadi didaerah Sungai Raya Dalam ini adalah didaerah hilir (dekat muara). Adapun penyebab terjadinya genangan ini diantaranya penyumbatan serta banyaknya sedimentasi yang ada disaluran sehingga pada saat pasang dan curah hujan yang tinggi, saluran tidak mampu menampung air berlebih tersebut.

Dengan demikian perlu dilakukannnya normalisasi sungai misalnya dengan mendalamkan sungai (pengerukan sedimentasi) kapasitas tampungnya sesuai dengan dimensi saluran yang direncanakan. Selain itu, normalisasi perlu dilakukan untuk membersihkan saluran dari vegetasi yang tumbuh terutama didaerah hulu sungai. Banyaknya vegetasi yang tumbuh dapat menyebabkan nyamuk untuk bebas bersarang disaluran sehingga menimbulkan bibit penyakit bagi masyarakat yang tinggal disekitar daerah tersebut. Selain itu, dapat menyumbat aliran air dan menyebabkan berkurangnya kecepatan air.

\section{Kesimpulan}

Dari penelitian yang telah dilakukan maka dapat disimpulkan:

1. Berdasarkan hasil simulasi program Duflow didapatkan debit aliran pada daerah hulu sebesar $7,845 \mathrm{~m}^{3} / \mathrm{dtk}$ dengan dimensi saluran untuk lebar penampang sebesar $12,57 \mathrm{~m}$ dan kedalaman sebesar $2,60 \mathrm{~m}$. Pada daerah tengah debit aliran sebesar $8,040 \mathrm{~m}^{3} / \mathrm{dtk}$ dengan dimensi saluran untuk lebar penampang sebesar $12,88 \mathrm{~m}$ dan kedalaman sebesar 2,60 m. Sedangkan pada daerah hilir debit aliran sebesar $8,862 \mathrm{~m}^{3} / \mathrm{dtk}$ dengan dimensi saluran untuk lebar penampang sebesar 13,68 m dan kedalaman sebesar 2,70 m. Sehingga dapat disimpulkan bahwa dimensi saluran Parit Sungai Raya mampu menampung kapasitas debit maksimum akibat pasang surut dan curah hujan yang tinggi. Namun masih ada beberapa titik dikawasan ini yang mengalami genangan banjir.

2. Adapun permasalahan yang mengakibatkan terjadinya banjir maksimum di beberapa titik di kawasan Parit Sungai Raya ini masih dipengaruhi oleh pasang surut dan curah hujan yang tinggi, yang dapat dilihat dari banyaknya vegetasi yang tumbuh dibagian hulu Parit Sungai Raya, terjadinya sedimentasi pada dasar sungai yang mengakibatkan kapasitas tampung berkurang, penyempitan alur sungai akibat banyaknya pemukiman penduduk, kurangnya pemeliharaan terhadap saluran yang ada.

3. Solusi pemecahan masalah banjir maksimum adalah dengan melakukan normalisasi sungai sesuai dengan dimensi saluran yang direncanakan. Sedangkan alternatif penanggulangan lainnya yang bisa diterapkan di kawasan Parit Sungai Raya diantaranya melakukan perbaikan serta meningkatkan operasional dan perawatan pada sistem drainase Parit Sungai Raya serta melakukan penyuluhan kepada masyarakat terkait dengan perilaku membuang sampah sembarangan dan membangun tempat tinggal dipinggir sungai.

4. Pola aliran dalam drainase Parit Sungai Raya adalah pola siku, dimana didaerah sungai raya terutama bagian hilir ini mempunyai topografi dengan elevasi sebelah kanan (daerah sungai raya bagian kuburaya) lebih tinggi daripada sebelah kiri (wilayah sungai raya bagian kota) serta Parit Sungai Raya ini sebagai saluran pembuangan akhir didaerah tersebut. 


\section{Ucapan Terima Kasih}

Penulis mengucapkan terima kasih yang sebesar-besarnya kepada Allah SWT atas rahmat dan karunia yang telah diberikan selama ini. Kedua orang tua yang tiada hentinya memberikan do'a, dan semangat dalam menjalankan skripsi ini. Tidak lupa juga penulis ucapkan kepada Ibu Ir. Hj. Kartini, MT dan Bapak Stefanus Barlian Soeryamassoeka, ST., sebagai pembimbing serta Bapak Ir. H. Nashrullah Chatib, M.T dan Bapak Winardi Yusuf, S.T., M.T, sebagai penguji. Serta teman-teman dan semua pihak yang tidak dapat saya sebutkan satu per satu yang telah banyak membantu baik dalam bentuk tenaga maupun motivasi.

\section{Referensi}

Delft. 1989. Duflow. The Nederland

Dinas Pekerjaan Umum. 2008. Laporan Akhir Perencanaan Master Plan Drainase Kota Pontianak. Pontianak : PT. Bayu Pratama Khatulistiwa.

Joesron Loebis. 1992. Banjir Rencana Untuk Perencanaan Bangunan Air. Cetakan Kedua. Penerbit Departemen Pekerjaan Umum. Jakarta.

Notodihardjo, Mardjono. 1998. Drainase Perkotaan. Jakarta : UPT Penerbitan Universitas Tarumanegara.

Suripin. 2004. Sistem Drainase Perkotaan yang Berkelanjutan. Andi Offset. Yogyakarta.

Wagenigen, 1992. Duflow version 2.04. The Nederlands. 